Portland State University

PDXScholar

1991

\title{
One woman, one child : the implications of the one- child-family policy for Chinese women
}

Tao Shi

Portland State University

Follow this and additional works at: https://pdxscholar.library.pdx.edu/open_access_etds

Part of the Sociology Commons

Let us know how access to this document benefits you.

Recommended Citation

Shi, Tao, "One woman, one child : the implications of the one-child-family policy for Chinese women" (1991). Dissertations and Theses. Paper 4286.

https://doi.org/10.15760/etd.6169

This Thesis is brought to you for free and open access. It has been accepted for inclusion in Dissertations and Theses by an authorized administrator of PDXScholar. Please contact us if we can make this document more accessible: pdxscholar@pdx.edu. 
AN ABSTRACT OF THE THESIS OF Tao Shi for the Master of science in Sociology presented November 15, 1991.

Title: One Woman, one Child -- The Implications of the one-Child-Family Policy for chinese Women

APPROVED BY THE MEMBERS OF THE THESIS COMMITTEE:
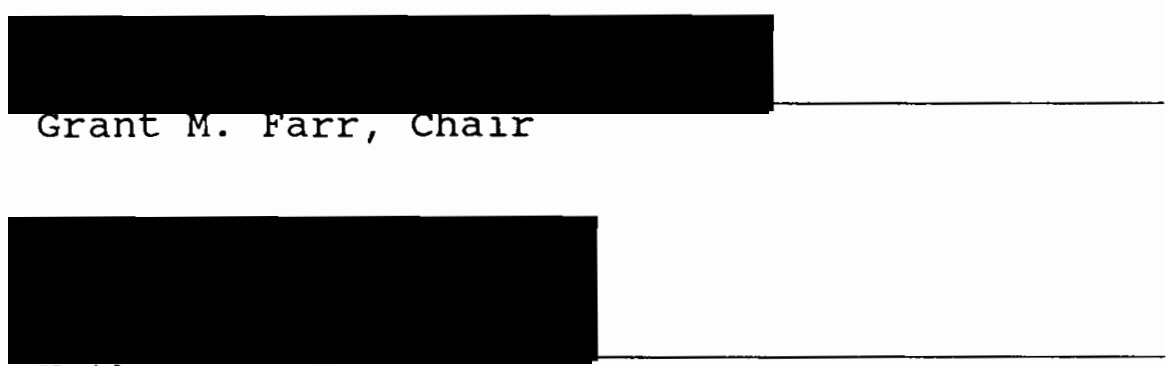

Kathryn A. Farr

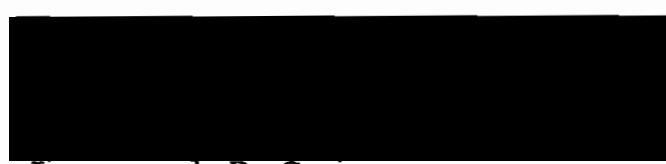

Leonard D Cain

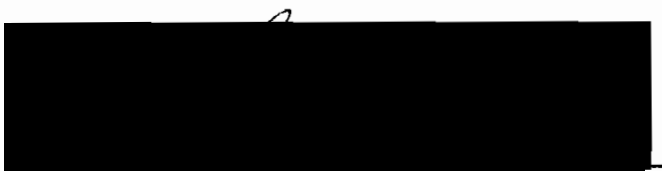

Mel Gurtov .

Since few studies have explicitly focused on the impact of China's one-child-family policy on chinese women, this thesis is designed to explore this aspect. The implication of the policy for both urban and rural women is studied, particularly its influence on women's fertility behavior, labor roles, and on social, health and family status. The 
focus of the study is to explore the changes of women's lives associated with the one-child-family policy, and advantages and disadvantages, even contradictions the policy has brought to women's lives.

The thesis involves library research, utilizing as sources a) descriptive statistical data (e.g., Chinese Population Yearbook; b) historical and interpretive research (e.g., studies cited in the literature review section); and c) media accounts (e.g., women of China, a monthly magazine; Beijing Review, a weekly magazine, and China Today, a monthly magazine).

The descriptive data analysis shows that the policy benefits urban chinese women more than it does women in the countryside. This is mainly because most of the incentives, such as space for housing, wage bonuses, and extended maternity leaves, function effectively among urban women. In contrast, these incentives turn out to have little appeal to rural families, especially rural women. What's more, the associated disincentives seem to make rural women's lives even harder. In addition, the deeply-rooted feudal ideas together with the conflict between the policy and reality have put rural women into a more difficult situation than urban women. In short, the one-child-family policy is more threatening to rural women than to urban women in China.

China needs to reduce its huge population. Women in China need to improve their status at home as well as in society. Is 
the one-child-family the best solution? The thesis concludes with a discussion of this issue. 
ONE WOMAN, ONE CHILD --

THE IMPLICATIONS OF THE ONE-CHILD-FAMILY POLICY

FOR CHINESE WOMEN

TAO ${ }_{\text {SHI }}$

A thesis submitted in partial fulfillment of the requirements for the degree of

\author{
MASTER OF SCIENCE \\ in \\ SOCIOLOGY
}


TO THE OFFICE OF GRADUATE STUDIES:

The members of the committee approve the thesis of Tao Shi presented November 15, 1991.
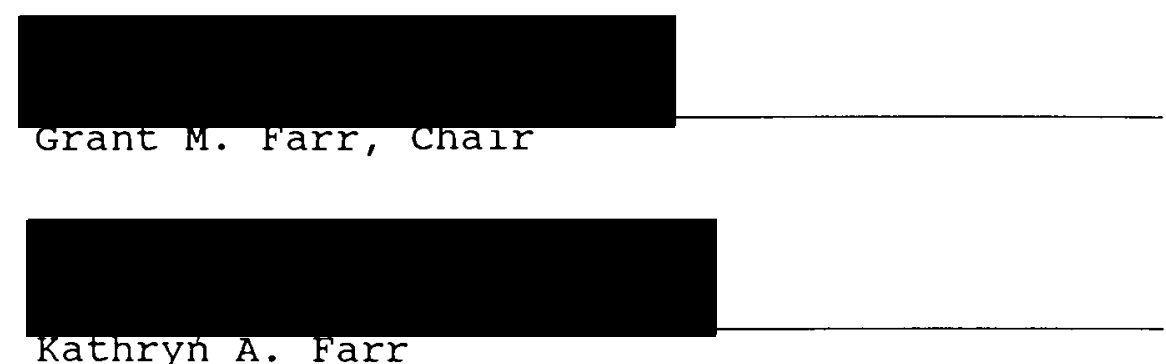

Kathryn A. Farr

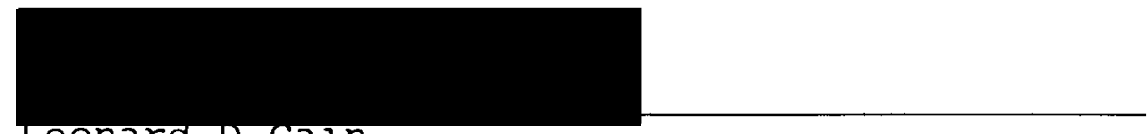

Leonard D cain

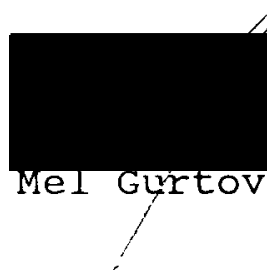

APPROVED :

Grant M. Farr, Chair, Department of Sociology

C. William Savery, Vice Provost for Graduate Studies and Research 
TABLE OF CONTENTS

PAGE

LIST OF TABLES

LIST OF FIGURES

CHAPTER

I INTRODUCTION . . . . . . . . . . . . . . 1

Statement of Problem . . . . . . . . 2

Hypotheses . . . . . . . . . . . . 4

II HISTORICAL BACKGROUND . . . . . . . . . . . 5

II THE ONE-CHILD-FAMILY POLICY • . . . . . . • . 13

IV THE GENERAL INFLUENCE OF THE POLICY ON CHINESE WOMEN . . . . . . . . . . . . . . . . . 18

$\mathrm{V}$ IMPLICATIONS OF THE POLICY FOR URBAN WOMEN • 23

Fertility Rate and Educational Level • . 25

Improved Social Images . . . . . . . 28

The Policy and the Feminist Movement. . 34

Changed Attitudes . . . . . . . . 39

Incentives for Young Mothers . . . . . 43

VI IMPLICATIONS OF THE POLICY FOR RURAL WOMEN • 49

Universal preference for Sons . . . . 49

Female Infanticide . . . . . . . . 52

Wife-beating and Wife-abandonment . . . 57 
"Floating Population" . . . . . . . . 62

Birth Control and Rural Women . . . . 65

VII CONCLUSION . . . . . . . . . . . . . 71

REFERENCES •. . . . . . . . . . . . . . . . 74

APPENDIX. . . . . . . . . . . . . . . . . 78 
I China's Birthrate -- Comparisons with the Rest of the World, 1988 . . . . . . . . . . . . 15

II Women's Average Age at Marriage, by Year of Marriage and Place of Residence . . . . . . 19

III Level of Education of Rural Women in 1980 . . 27

IV Major Employment Motives of Urban Women . . 30

V First Marriage of Chinese Women in 1987 . . . 41

VI Urban \& Rural Women's Birth Control Rate by Method in 1987 . . . . . . . . . . . . . . 41

VII Unplanned Birth in 1987 . . . . . . . . . 42

VIII Number and Rate of women Getting One-Child Certificates in 1987 . . . . . . . . . . . . 43 


\section{LIST OF FIGURES}

FIGURE

PAGE

1. Demographic Articles in Newspapers \& Journals (1950-1988) . . . . . . . . . . . . . . . 7

2. Uneven Birthrates in China . . . . . . . 55

3. Cartoon . . . . . . . . . . . . . 70 
CHAPTER I

\section{INTRODUCTION}

The socialist revolution in 1949 was accompanied by structural changes that began to upgrade the status of women in China. The Marriage Law of 1950 removed certain legal restrictions on women, and allowed further advances. The Law not only abolished the feudal marriage and family system of marriage based upon arbitrary decision by a third party, or on mercenary marriage, but also put into effect the new democratic marriage and family system based on the free choice of partners, on monogamy, and on equal rights for both sexes (Encyclopedia of China's Law). The Marriage Law was the first law that the new People's Republic of China promulgated after its founding in 1949 (Women of China, 1990), and it was the first democratic marriage law in Chinese history. Before that, the feudal patriarchal family system went hand in hand with arranged marriages, male chauvinism and indifference to women's wants and feelings. In recent years, the government has been carrying out the one-child-family policy, which, to some extent, has helped improve the status of women even more. Generally speaking, the single-child-family policy is one of the most important new policies which have changed the face 
of China since the death of Chairman Mao Zedong in 1976. Its implications for the future social structure and development of China are fundamental. The policy, inaugurated in 1979, had its origins in the government's concern that if population growth is not slowed down and eventually reversed, China can not achieve the economic growth for which it is striving. Therefore, since 1979, all couples of child bearing age have been urged to limit their offspring to one child. In order to realize this goal, heavy political and social pressure has been used and a vast set of incentives and disincentives has been developed to reward those who obey the national program and to penalize those who do not. However, since the policy conflicts sharply with traditional Chinese values and is problematic in other ways, it is difficult to carry out.] Its success or failure will have far-reaching implications for the economic, social and political development of China. Furthermore, this Chinese experiment surely has important implication for the nations throughout the world which are undergoing early stages of urbanization and so called modernization, since rapid population expansion continues to confront most such nations.

\section{STATEMENT OF PROBLEM}

of all the post-Mao population studies done on China so far, most have focused on social and family structural changes 
caused by the one-child-family policy, and on the influence of the policy on China's economy and four modernizations.' Little attempt has been made to examine the subtle but important changes the policy has brought to the status of chinese women. Also lacking are comparisons of the effects of such changes on urban and rural women in China. Therefore the purpose of this thesis is to examine the impact of China's single-childfamily policy on chinese women and the possibly differential influence of the policy on rural and urban women. Descriptive statistics will be used to illustrate the changes in women's lives and more specifically the differential changes between rural and urban women. Special attention will be given to changes in women's educational levels, employment status, and their positions at home as well as in society. The thesis will begin with historical background, followed by an explanation of the family-planning policy. Then there will be an analysis of the current situation of chinese women, using data collected from various sources, to explore the advantages, disadvantages, and major changes in women's lives associated with China's single-child-family policy. This study is significant because the success or failure of the singlechild-family policy initiatives, and thus the future development of China, rests heavily upon the evolving status

1 Four modernizations refer to modernizations in industry, agriculture, defense and science. 
of Chinese women, especially in regard to their childbearing roles, and their acceptance or rejection of that status.

HYPOTHESES

Based on analysis of available data on the subject at hand, two hypotheses are advanced:

1. Since the implementation of the one-child-family policy, changes in women's lives in China have occurred, specifically:

a. Women's age at first marriage has increased;

b. Years spent in childbearing and child rearing have decreased;

c. Social welfare for young mothers (of only one child) has increased ;

d. The percent of women of childbearing age who use contraceptives has increased.

2. The one-child-family policy benefits urban women much more than it does women in the countryside. 
CHAPTER II

\section{HISTORICAL BACKGROUND}

China is the most populous country on earth, with approximately 1.2 billion people, over a fifth of the world's total population (Hou, 1991). Overpopulation here, as elsewhere, is associated with serious social and economic problems.] To use only $7 \%$ of the world's arable land to feed $22 \%$ of the world's population is not an easy accomplishment (Guo, 1990; Hou, 1991). Its average annual per capita gross national product, which is equivalent to 400 U.S. dollars, ranks China among the lowest income countries in the world (Hou, 1991). Also, there are 180 million (one-sixth of the population) illiterate and semiliterate people in china, about a quarter of the world's total (Hou, 1991). In addition, overpopulation impairs the development of China's industry, medical care, and social welfare, as well as the quality of women's lives.

Unfortunately, the leaders of China did not anticipate the eventual problem of population when the People's Republic of China was established in 1949. In fact, the leaders were pronatalists, encouraging large families, in accordance with the prevailing cultural norm that most of the leaders shared. 
Mao Zedong, for example, at one time encouraged the expansion of China's population. He was not worried about the country's having too many people, because, as he said, "Every stomach comes with two hands attached" (Worden, 1988:117).

In the early 1950s, Professor Ma Yin-chu, a Chinese demographer, economist and former president of Beijing University, became convinced that china had to act seriously to control the rapid growth of the population. He did a thorough study of china's population and presented a theory of population control. Mao Zedong, however, was not convinced of the need for control. Instead he regarded Ma's suggestion as a "bourgeois" Malthusian theory. He believed that, "Of all things in the world, people are the most precious. Under the leadership of the communist party, as long as there are people, every kind of miracle can be performed" (Worden, 1988:123). He also believed that the chinese masses were a major component of the productive forces, in fact the only component that was in healthy condition after the 8-year war with Japan and the 3-year Liberation War against Kuomindang. In the mid 1960s, the study of demography itself was forbidden. For the following ten years almost no professional work was done in the field of population studies. Related disciplines such as sociology and statistics had similar fate (Li, 1962; Wong, 1979). This suspension of demographic and related studies has had its costs. Basic information on the population characteristics of that period is lacking today. 
Few professional demographic researchers were available then, and there were not enough library holdings of the necessary demographic literature (Coale, 1981). In 1978 there was only one research institution on population in the whole country. By 1981, the number had been increased to over 20 (Tien, 1981) .

The neglect of the population issue is also indicated by the lack of articles associated with this subject. (see Figure 1.)

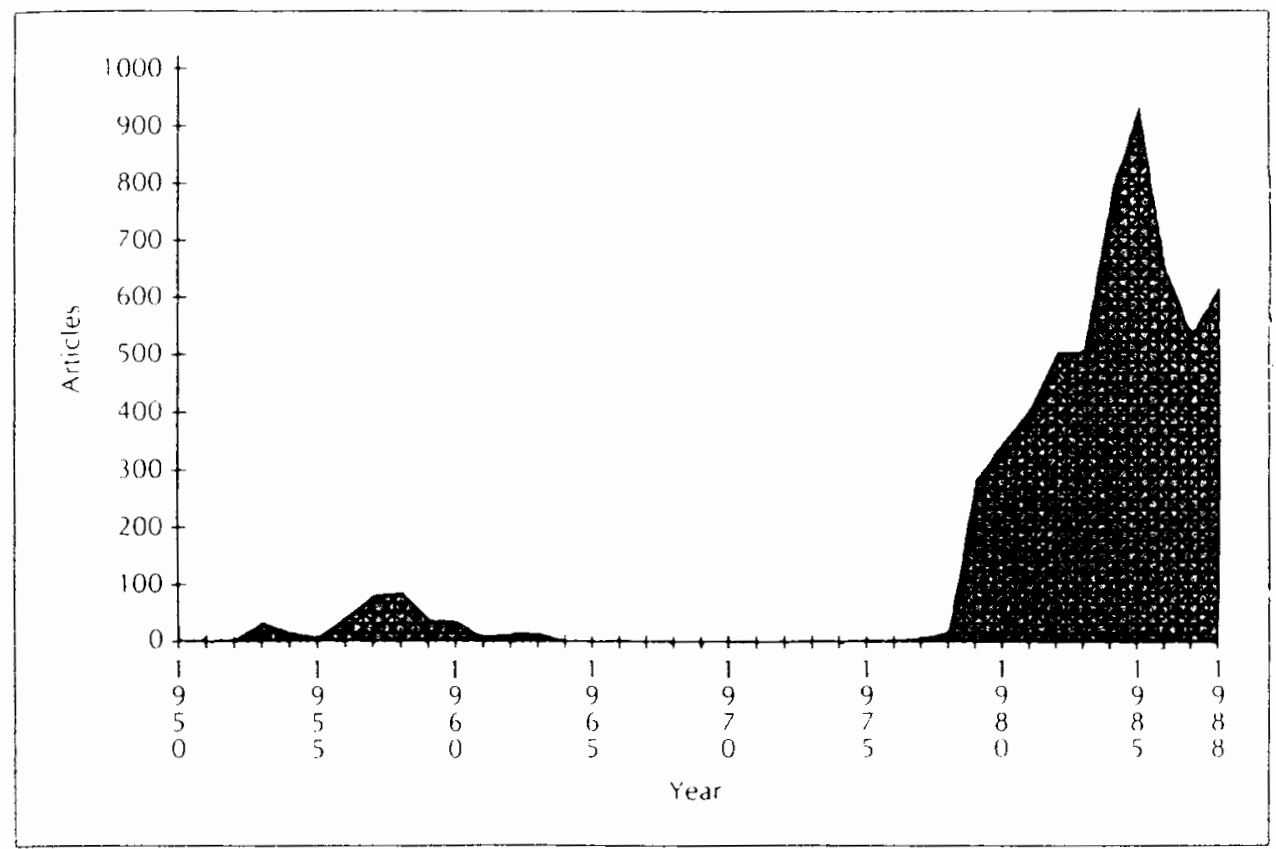

Fiqure 1. Demographic Articles in Newspapers and Journals (1950-1988). Source: The Journal of Asian Studies Vol.49, No.4, Nov.1990, P809.

Nevertheless, China did have, beginning as early as 1956, three population control campaigns before the implementation 
of the one-child-family policy.

The first serious efforts to control population growth occurred from 1956 to 1958 (China Today, 90). By then, the rapid growth of population in China was recognized not only by demographers in the West, but also by Mao. "We have this huge population," he wrote in 1956. "It is a good thing, but of course it also has difficulties... steps must therefore be taken to keep our population for a long time at a stable level, say, of 600 million. A wide campaign of explanation and proper help must be undertaken to achieve this aim" (Worden, 1988:123). Yet, the birth control drive made little progress during the first campaign. The main reason was the lack of an effective field organization for translating the Party's policies into action. There is no evidence that a national birth control organization had evolved by the time the Great Leap Forward ${ }^{2}$ interrupted the effort in the spring of 1958 (Aird, 1990).

A second campaign for birth control began in 1962 under Zhou En-lai, but it was disrupted during the Great Proletarian Cultural Revolution ${ }^{3}$ in 1966.

2 The Great Leap Forward: In 1958, Mao Zedong reverted to his earlier idea that China's masses, fired by revolutionary enthusiasm, could produce far more than they consumed. He argued that both in agriculture and industry "miracles" of production were possible. Therefore he called for three years of all-out efforts to produce a "Great Leap Forward" all across the land.

3 The Great proletarian cultural Revolution started in 1966 and lasted for 10 years. Its ostensible purpose was to eliminate influences that Mao Zedong believed had corrupted 
The third birth control campaign, again under zhou, began in 1970 and has continued to the present.

Generally speaking, state intervention in the internal affairs of the family can be divided into 3 stages:

1. In the 1950s and 1960s, the government had hoped to reduce population growth by a series of voluntary measures, such as education campaigns and encouragement of the use of contraception. Young people were primarily urged to plan fertility rather than to reduce the population. Just as individuals and couples were encouraged to plan their work, life, study and leisure, so they were encouraged to plan their childbearing. What was emphasized throughout the first stage was that the decision to space and limit births was a private family matter in which the individual couples themselves made decisions according to their own personal circumstances and wishes.)

2. In the 1970s, the hope that people would voluntarily limit themselves had evolved into a series of agreements made at the local level. That is, the urban and rural communities were allowed to negotiate birth quotas with their resident families. Actually the early 1970 s marked the beginning of a sustained attempt to implement family planning in china as part of a national population policy to reduce the birth rate.

the Chinese Communist Party, but it was also an attempt by Mao to regain full control of the Party organization by destroying former colleagues who had attempted to limit his powers after the disaster of the Great Leap Forward. 
"Wan, Xi, Shao" ("late, spaced and few") was the popular slogan at that time. That is, the major objective was reduction of fertility through later marriage, longer spacing and fewer children per couple. Program performance was measured by the late marriage rate, the planned birth rate, the birth limitation rate, live birth rate and natural increase rate (Chen, 1985). The second campaign achieved more success than the first one, including more effective contraceptive methods. Intrauterine devices and a new suction device for carrying out abortion began to be put into use for the first time. Yet both methods were available only in urban areas (Aird, 1990).

3. By the end of the 1970s, however, it had become clear to the government leaders that family plans were too important to be left open for local negotiation. According to statistics, population in China had grown by more than 75\% between 1949 and 1978 (from 540 million to more than 900 million) (Smith, 1991). Although food grain production increased from 163.90 million tons in 1952 to 304.75 million tons in 1978 (Ishikawa, 1983), the output of grain per capita actually dropped because of the fast population growth. "Raising 600 million children born since 1949 has required a total expenditure of 1,300 billion yuan -- roughly $30 \%$ of the total gross national income over that same period," said Liu Zheng in $1982 .{ }^{4}$

In

4 Liu Zheng is the director of the Population Research Institute, Chinese People's University, and vice president of China's Demographic Society. 
addition, two-thirds of the chinese people would be under age 23 by 1984 , with many years of healthy fertility before them. Thus, china was faced with a demographic situation in which a rapidly expanding population of childbearing age needed to be called upon to accept drastic reduction in fertility. Even a one-child-family policy would not stop the tide of population growth in the short run.

Given this alarming situation, chinese researchers and planners began in the mid-1970s to consider new family limitation strategies and goals. Finally planners devised a drastic program for reducing the chinese population over the course of the next century, which aimed at stabilizing the population at about 700 million.

Beginning immediately, drastically reduce the average birth rate to reach the final fertility rate of one child per couple by 1985 and maintain that level... by 2070. That is, 90 years from now, the total population should be stabilized at about 700 million... maximum efforts [must] be made in the next decade or two to advocate that all fertile women must begin now. It will be like a relay race, with each generation striving towards this goal.

Therefore when the Second Session of the Fifth National People's Congress met in June, 1978, the question of population growth was discussed. The policy to encourage each couple to have only one child was announced in January, 1979. In september, the following year, the PCC (Party Central Committee) issued an "open letter" to call on all party and 
youth league members to take the lead in having only one child. Thus the government finally decided to take control of individual family decision-making. And the "one-child-family" policy had become a national goal. 
CHAPTER III

THE ONE-CHILD-FAMILY POLICY

As early as 1968, when China's fertility level reached its second highest peak since 1950, the total fertility rate was 7.025 children per woman of completed reproductive age. (The total fertility rate of women refers to the number of times a woman gives birth in her life.) In 1971, when the government started the third birth control campaign, the total fertility rate was still a high 5.442 (Chen, 1985). A decade later in 1981, only two years after the application of the one-child-family policy, the total fertility rate had dropped to 2.238 (Chen, 1985). Such a dramatic fertility transition in a large country and in so short a time has surely not been accomplished elsewhere to date. This achievement is even more impressive because the transition has taken place without a significant improvement in living standards or socio-economic development taking place before or during the transition period (Chen, 1985).

Generally speaking, fertility reduction goes hand in hand with an increase in modernization and urbanization. For most societies, modernization precedes a significant fall in the birthrate, mainly because it takes many decades of education 
and improved living conditions before families are convinced it is in their best interest to limit their reproduction rate. China's situation is really exceptional. In china, the birth rate fell very rapidly before modernization. For example, in 1970, the birth rate was 33.59 per thousand, but it was 20.83 per 1,000 in 1989 (Beijing Review, 1990). If we compare China's demographic statistics in 1985 with those in other parts of the world (see Table I), we see that the birthrate is lower than the world average and is approaching that of the developed countries (although it is still not as low as Chinese demographers had expected). In comparison to other developing countries, China's birthrate is extremely low (20 as opposed to 35 per 1,000).

China's situation is exceptional also because of the reciprocal relationship between China's modernization and the control of its population. To put it in another way, on the one hand, the chinese government hopes that the development of modernization and urbanization will lead to the decline in fertility. On the other hand, the government realized that the very development of modernization depends heavily on the degree to which China can reduce its population growth rate. In order to handle the dilemma of reducing population and developing the economy, Chinese government finally decided to use the dramatic strategy and tactic --- the one-child-family campaign, and has had authority to implement the strategy rather effectively. 
TABLE I

CHINA'S BIRTHRATE --- COMPARISONS WITH

THE REST OF THE WORLD

1988

\begin{tabular}{|l|r||}
\hline \multicolumn{1}{|c|}{ REGION } & BIRTH RATE (PER 1,000) \\
\hline CHINA & 21 \\
\hline WORLD & 28 \\
\hline DEVELOPED COUNTRIES & 15 \\
\hline LESS DEV. (EXCL.CHINA) & 35 \\
\hline JAPAN & 11 \\
\hline SWEDEN & 12 \\
\hline U.K. & 13 \\
\hline CANADA & 15 \\
\hline AUSTRALIA & 15 \\
\hline U.S. & 16 \\
\hline NEW ZEALAND & 16 \\
\hline INDIA & 33 \\
\hline HAITI & 41 \\
\hline BANGLADESH & 43 \\
\hline ETHIOPIA & 46 \\
\hline MALI & 50 \\
\hline
\end{tabular}

Source: extracted from Population Reference Bureau, 1988, World Population Data Sheet (Washington D.C.; Population Reference Bureau, Inc.

Although this campaign is widespread, there is no single national family planning law (Davin, 1985; Renmin Ribao, 1980). The Fifth National People's Congress in 1980 expected to issue a national package, with some standardization of regulations, but it was unable to reach an agreement (Renmin 
Ribao, 1980). Thus the national program of incentives and disincentives proposed in 1979 was never passed. In general, the current population policy aims to control population growth, improve the quality of population, ensure the reproduction of healthy children and improve their upbringing. A couple is generally encouraged to have only one child; however, some couples can have a second child several years after their first birth (See Appendix for other exceptions). The detailed regulations are worked out by the local authorities in accordance with different situations. That is, to implement the one child family policy, various economic benefits and disincentives are applied. These regulations differ from one place to another, especially from urban to rural areas.

The major economic incentives in various provincial regulations include wage bonuses, extra work points, and housing priorities. Mothers who pledge to have one child will receive additional maternity leave. The only child is eligible for a range of benefits in kindergarten, school, and university enrollment, and priority in employment placement after graduation.

These incentives have been rather effective for people in the cities, but have had little appeal to rural families (Dalsimer and Nisonoff, 1987). For example, space within housing is not a problem for most rural families whereas it is a major problem for most urban families. Wage bonuses apply 
mainly to urban parents who earn wages at factories, offices, and enterprises, and seldom to agricultural rewards. Some wealthy rural enterprises offer bonuses, but they are lower than urban bonuses. Under the new agricultural responsibility system, both the work point incentives and extended maternity leaves are unlikely to have much effect. With the exception of free health care, the various welfare benefits are rarely available to most rural families. Because these incentives have not worked well in the countryside, some rural areas have sought to offer additional grain allotments, larger family plots, or job preference in commune industries to one-child families (Dalsimer and Nisonoff, 1987).

The punishments (disincentives) more often affect rural families, but their efficiency is limited. Some disincentives used in the rural areas include reductions in state grain allotments for second and third children, expropriation of family goods (such as television sets, bicycles, or sewing machines), fines on overquota births, or withdrawal of part of the families' fertile plots under the family responsibility system.

The one-child-family policy has affected almost everyone in the nation. Then what special effect does it have on Chinese women as a whole? The following chapter presents the major findings on changes in Chinese women's lives associated with the policy. 
CHAPTER IV

THE GENERAL INFLUENCE OF THE POLICY ON CHINESE WOMEN

In the past twelve years, during which the one-childfamily policy has been in effect, several general changes have occurred. The birth rate of china has decreased, and women's lives have been greatly changed in many aspects. This section will mainly deal with the impact of the one child family on Chinese women as a whole.

First of all, Chinese women's age at first marriage has changed. In 1972, the average age at marriage for urban women was 22.6 , and 21.0 for rural women. By the end of 1979, the first year of the implementation of the one-child-family policy and its associated late marriage programs raised the mean age at first marriage, which increased to 24.6 and 22.8 for urban and rural women respectively (See Table II). The results from a 1982 survey show that the average marriage age for urban and rural women had reached 25.19 and 22.54 respectively. In shanghai (the largest city in china) the average marriage age for women had jumped to 26.8 from 22.6 by 1981.

The increasing age for first marriage is mainly due to the tightly controlled marriage permits by local government. 
In the past, there was no serious control of age for marriage. Usually, soon after a man and a woman got engaged, they had a wedding ceremony, and announced their formal marriage to people around.

\section{TABLE II}

WOMEN'S AVERAGE AGE AT MARRIAGE, BY YEAR OF MARRIAGE AND PLACE OF RESIDENCE

\begin{tabular}{|r|r|c|}
\hline Year of Marriage & Urban & Rural \\
\hline 1972 & 22.6 & 21.0 \\
\hline 1979 & 24.6 & 22.8 \\
\hline
\end{tabular}

Source: H. Yuan Tien, 'Age at Marriage in the People's Republic of China', China Quarterly, March 1983.

After the one child family policy was announced in 1979, the central government issued a strict regulation to restrict young people from having an early marriage. The legal age for women to get married now is 22 . Since 1979, it has been extremely difficult to get a marriage permit before the age of 22. The purpose of this practice is to postpone the average marriage age of young women, and in turn delay childbearing age and finally reduce the nation's fertility rate.

Secondly, Chinese women, generally, no longer have the alternative to give birth to more than one child. The "birth quota" system in the one-child-family policy indicates that each married woman can have only one child. And birth quotas 
are usually decided upon nationally and distributed downward to provinces, cities, towns, counties, and other basic local levels. Therefore, before a woman gets pregnant, she is expected to get a birth quota certificate from her local official in charge of birth control. Or she must report to the local birth control office within the first three months of her pregnancy. Failure to do so will result in a fine or/and "mobilization" to get an abortion. In addition, without this official authorization, she is unable to get prenatal care because she does not have the authorization paper to show to the local health clinics or hospitals. And the "unplanned" new-born baby will have difficulties later in registering for grain allotments, schooling and medical care.

Third, the percentage of women using contraceptives has gone up very rapidly since 1979.

Even during the early 1970s, contraceptives were seldom used in the country. In some poor and remote areas, contraception had never been heard of. A decade later, in 1982, only three years after the implementation of the one child family policy, this had changed dramatically. "China's contraceptive prevalence rate was as high as that in developed low-fertility countries. According to the one per thousand sample fertility survey carried out in $1982,69.46 \%$ of the married women of reproductive age (aged 15-49) were contracepting" (Chen, 1985). By comparison, in Japan only $61 \%$ of the married women age 15-49 were practicing contraception 
in 1976, and 69\% of married women aged 15-44 in the U.S. were contracepting in the same year (Yan, 1983; Davis-Friedmann, 1983)

The most frequently used contraceptive method among Chinese women is the IUD, which accounts for $50.2 \%$ of all contraceptives in China (1/1,000 survey in 1982). In the urban areas, $39 \%$ of women rely on IUDs, while the percentage for rural women is $53 \%$ (Chen, 1985).

The second most popular contraceptive method used in China is sterilization, accounting for $35 \%$ of China's total contraceptives in 1982. Of this $35 \%, 25 \%$ are women users (Chen, 1985).

Several varieties of oral contraceptives and condoms are also utilized in China, but mainly among urban women (Chen, 1985)

The increase in the late marriage rate for females, the prevalent usage of contraceptives among women, and the policy of "one woman, one child" have brought a sharp fertility decline to the nation. For example, in 1973, three years after the third birth control campaign, the total fertility rate was still 4.539 (2.387 and 5.008 for urban and rural areas respectively). In 1980, however, only one year after the implementation of the one-child-family policy, the total fertility rate dropped to 2.238 (1.147 for urban region and 2.480 for rural region) (Chen, 1985; Qian and Xian, 1983). The crude birth rate dropped from 33.59 per thousand in 1970 to 
20.83 per thousand in 1989 (Beijing Review, Oct.15-21, 1990). Meanwhile, the natural growth rate decreased from 25.83 per thousand to 14.32 per thousand (Beijing Review, 1990). "These indices are below the average of other developing countries," says Peng Pei-yun, "The rapid population growth is basically under control." 6

Then what advantage and disadvantage do these practices have for Chinese women's daily lives? Do they have any influence on women's status at home and social images in society? Do urban and rural women get the same benefits form the policy? Are there any contradictions between the policy and Chinese women's interests? How can we predict the impact. on later generations of women? The rest of the paper will be devoted to a discussion of these and related issues.

6 Peng Pei-yun has been the Minister of the state Family Planning Commission since 1988. She said these words in an interview with the reporters from Women of China and China Today (See Women of China, Vol XXXX No.8 Aug. 1991:28) 


\section{CHAPTER V}

IMPLICATIONS OF THE POLICY FOR URBAN WOMEN

According to Ralf Dahrendorf, a famous conflict theorist in sociology, all institutional patterns display two mutually contradictory sets of role expectations ---- one to obey, the other to revolt -.-- and therefore actors must decide which set they will follow (Porter and Taplin, 1987). The one-childfamily policy can be regarded as a kind of institutional pattern, which generates contradictions. [It generates the contradiction between state's interests and the interests of the people.) (If we consider urban and rural women as two different groups of actors, their basic reaction to the onechild-family policy can be described as "One obeys, the other revolts". That is, one is compatible with the policy, the other is contradictory to it.

The implication of the policy and the reaction of both urban and rural women toward the policy can be explained also by the "theory of demographic change and response" (Weeks, 1989:78). This theory emphasizes that people usually respond to the demographic change, but their response will be in terms of personal goals, not national goals. "People must perceive a personal need to change behavior before a decline in 
fertility will take place, and the kind of response they make will depend on what means are available to them." (Weeks, 1989:83). This theoretical perspective suggests a very important link between the every day lives of individuals and the kinds of population changes that take place in society.

Based upon the fragments of theories discussed above, the following two chapters will make a detailed analysis of the implications of the one-child-family policy for urban and rural women, and their different reactions to it.

Since 1979, considerable change has taken place in women's lives. Yet these changes have occurred unevenly due to geographical and economic impediments. The implications of the new family policy for both urban and rural women are even more difficult to assess. Generally speaking, the policy has turned out to have more advantages for urban women than for rural women. Available evidence suggests that the status of urban women has improved. Urban women seem to be much more willing to obey and accept this policy rather than to revolt or strongly oppose it. For instance, the overall attitude of urban women toward the gender of children has changed so that a female child is as acceptable as a male child; the time urban women spend in child rearing has been greatly shortened; urban women's educational levels have increased; the status of urban women at home has been raised; the social welfare and health care for young urban mothers have steadily improved; and urban women are much more active in participating in 
working out of home, and engaging in the feminist movement. The following section will examine the impact of the onechild-family policy on urban women's reproductive behavior and its relation to women's educational level.

FERTILITY RATE AND EDUCATIONAL LEVEL

One effect on urban women's life is the decline in the number of years that they devote to caring for their children. According to the one per thousand fertility survey in 1982, the total number of children a married urban woman bore during 1952-55 was 6.574 . The total number increased to 7.622 during 1955-58. Since the implementation of the one-child-family policy in 1979, the total fertility rate has dropped sharply. According to Li Bohua and Ronald Freedman, between 1979 1982, the average number of children an urban woman has dropped to 1.663 .

In the past, then, a woman had to spend much of her middle years, say from her early 20 s into her mid 40 s or beyond, engaging in childbearing and child rearing, accompanied by associated housework. According to Professor Zhu Chuzhu's survey study in $1987,{ }^{7}$ Chinese women before the 1960s were mainly concerned with family life and human

7 Professor Zhu Chu-zhu in Xi'an Jiaotong University conducted a special investigation on the life cycle of Chinese women in 1987. Women involved in this survey are from both urban and rural areas from 21 Provinces. She got back 1,612 questionnaires for this survey. 
reproduction. They had little education and were scarcely aware of the experience of adolescence. "During their short life span of 50 years, 20 years would be occupied by frequent pregnancies and the raising of family (children)" (Zhu, 1991). The one-child-family policy has legally liberated women from the long period of child bearing and enabled them to develop their own interests, to seek after their own career, and to improve their own educational level. Just as professor $\mathrm{Zhu}$ stated, "Family planning has greatly reduced the number of children a woman now receives (a woman would bear). The average number of births has now dropped from five or six, to two or three in a woman's life time." "They (Women) now practice late marriage, late childbearing and less of it." She says, "Less time is spent on giving birth nowadays and they (women) receive an education for over ten years" (Zhu, 1991). ${ }^{8}$ Ten years of education for urban women might not be so significant in some relatively developed countries. In China, it is indeed an important fact. It is even more so when

8 zhu Chu-zhu is a professor of demography and economics at Jiaotong University in Xi'an, China. In 1988, Zhu participated in the project of "Co-ordinating Chinese Population Growth with Social and Economic Development," which won first prize in the National Award for Progress in Science and Technology. Zhu is an authority in the field of population studies concerning chinese women. She is the first chinese expert to undertake research on the life cycle of women. At present, she is responsible for a research project about "women's employment and child birth in China," sponsored by the UNFPA (United Nations Family Planning Association). $\mathrm{zhu}$ is endeavoring to improve the social status of Chinese women. She often gives lectures on population theory and control, and its importance for the social and economic development of china. 
compared to the educational level of rural women in China (See Table III).

TABLE III

LEVEL OF EDUCATION OF RURAL WOMEN IN 1980

\begin{tabular}{||l|l|}
\hline Level of education & $\%$ of women \\
\hline Senior Middle School & 3.5 \\
\hline Junior Middle School & 9 \\
\hline Primary School & 45.0 \\
\hline Illiterate & 42.0 \\
\hline & 100 \\
\hline
\end{tabular}

Source: Jingji Yanju (Economic Research), June 20, 1982.

Based on the survey of 707 peasant women of childbearing age in 1980 , we can see that only $3.5 \%$ of rural women have ten years education, $9.5 \%$ of them have a seven to eight years education. Of these women, $45 \%$ go to school for five or six years, and $42 \%$ are simply illiterate. A report appearing in Women of China, March, 1990, revealed that in the past ten years, the serious educational situation of rural Chinese women has not changed much.

Unlike rural women, more and more women in the cities have begun to engage in higher education. According to Worden, of all the college students in China, $24 \%$ of them are urban 
women. Some of them are even at the top of the ivory tower. ${ }^{9}$

A postdoctoral research system was first introduced to China in 1985. According to wang Xiaoming's report, since then, 161 postdoctoral research centers have been established, and 935 people have studied or are studying in these centers. Among these people, 39 are urban women.

Thirty-nine is a small number, but it is a positive sign for women's, especially of urban women's, desire to get more education and be equal with men.

"Since the practice of family planning in 1979, the dropping of birth rate has completely changed the female life cycle (in China)" (zhu, 1991). Like the Marriage Law in 1950, which abolished the feudal marriage system restricting women, the one-child-family policy further upgrades women's status and legally liberates them from endless childbearing and child rearing.

\section{IMPROVED SOCIAL IMAGES}

As previously mentioned, the one-child-family policy has helped reduce the fertility rate and raise urban women's educational level steadily since it was first issued in 1979. Women's education is one of the most basic and important

9 The temporary educational structure in china is often referred to as an Ivory Tower. The higher you go up the tower, the fewer people there are. Thus those engaged in postdoctoral research may be regarded as people at the top of the ivory tower. 
factors in liberating women and changing their social images. Generally, education credentials seem to be more important for females than males in professional careers. Male superiors, let us suggest, are usually less confident in judging women's ability to do a job than in judging their education. The more education a woman has, the more likely she is to be employed (Farr, 1990; Fox, 1989). When women are freed from the burden of childbearing, they have more time and more opportunities to engage in education and special training. And the greater their educational level, the greater is their participation in production and in various kinds of social labor. This is important in a country with an age-old feudal tradition of male supremacy and contempt for women. The new breed of educated, capable women cannot be dismissed as having "long hair and little knowledge" (one of many such old sayings in the language). Many show remarkable ability. Quite a few of them have been selected as model workers and serve in local people's congress and other responsible bodies (Women of China, Vol. XXXIX, No.3, Mar.1990:18). One particular example is the rising number of women deputies in the National People's Congress and its Standing Committee. In 1954, at the First National People's Congress, women deputies comprised only $11.9 \%$ of the Congress membership and only 5\% of the Committee membership. But at the Seventh National people's Congress in 1988 , the number rose to $21.34 \%$ and $11.6 \%$ (Huang, 1990). 
In fact, the number of employed urban women has been increasing constantly since 1979 and now accounts for more than $37 \%$ of the working force in china. What are the major factors that make urban women work outside the home? Kang Jun and his colleagues did a "systematical and multi-aspected survey" in 1989. A sample of one thousand-eight hundred female workers and staff from a total of 90 enterprises and institutions in seven cities were involved in this survey. These researchers classified the major employment motives into the following six categories listed in Table IV.

TABLE IV

MAJOR EMPLOYMENT MOTIVES OF URBAN WOMEN

\begin{tabular}{||l|l|c||}
\hline \hline Order & \multicolumn{1}{|c|}{ Motive } & Percentage \\
\hline First & Generating Income & $72.9 \%$ \\
\hline Second & Striving equal social status with men & $66.3 \%$ \\
\hline Third & Making contributions to the society & $64.7 \%$ \\
\hline Fourth & Receiving recognition from society & $37.1 \%$ \\
\hline Fifth & Sharing in community life & $29.8 \%$ \\
\hline Sixth & Seeking employment because others do & $22.8 \%$ \\
\hline
\end{tabular}

Source: Women of China, June 1989, P43. 
to join the working force is financial (72\%). The second most important motive is to strive for equal social status with men $(66.3 \%)$. These two highest ranked motives suggest that many urban women have realized the strong relationship between economic independence and women's related social status. That is, economic independence can help women obtain equal social status with men. Above all, the results suggest a very obvious change in urban women's self-esteem and self-confidence.

In a male-dominated country like china, women traditionally (prior to the communist revolution in 1949) thought about themselves as consumers and their husbands as bread-winners and providers. They seldom went out to work and their bound feet confined them completely to the stoves and homes. The change in attitude toward working outside and money-making reflects a noticeable transition of ideology. It indicates that urban women have started to consider their working out of the home as essential to the family income. The part they play in the family life is no longer dependent or subordinate. A 1990 survey of more than 2,000 women residents in ten cities, including Beijing, Harbin and Shanghai, indicates that over $80 \%$ of urban women favor the employment of women. Some $90 \%$ of the women surveyed felt that doing well in their work was an important goal. And about $70 \%$ said that career and family were equally important to them (Beijing Review, Nov.12-18, 1990).

Shortly after the founding of the People's Republic in 
1949, there were only 2.6 million women workers and staff members in the nation's cities, about $7.5 \%$ of the total work force (Beijing Review, Nov. 12-18, 1990). "By 1989, urban women workers had numbered 51.37 million, accounting for $37.4 \frac{8}{6}$ of the nation's total. The 1989 ratio, which was nearly five times that of 1949, is among the world's highest for women workers. In 1986, the employment rate for women in cities and towns was $82 \%$ nationwide. In 1989 , the employment rate for women was as high as $95 \%$ in the Shenzhen special Economic Zone. ${ }^{10}$ Between 1987 and 1988, the employment rate for women was higher than for men during the same period (Huang, 1990). Beijing Review confirmed again in March, 1991 that China has more than 51 million female workers, about $37 \%$ of the total work force. In the light industry and service trades, women account for $47.1 \%$, and in joint ventures and foreignfinanced enterprises and institutions, they account for more than $50 \%$ of the staff.

of the nation's scientists and technicians, one-third are women and more than $10 \%$ of them hold professional titles such as professor, associate professor and senior engineer. There are 17,087 professors engaged in teaching in China's

10 In order to promote economic exchange and cooperation with foreign countries, a decade ago china began to establish Special Economic Zones (ENZs). Now there are five of them: Shenzhen, Zhuhai and Shantou in Guangdong Province, Xiamen in Fujian Province and the island province of Hainan. All are along the country's south and southeast coast. In these zones, special and more flexible preferential policies on outside investment are put into effect in order to attract capital from abroad. 
institutions of higher education and in research establishments and 1,570, or $9.2 \%$ of all professors, are women. Some 811 women, or $52 \%$ of all female professors, work in the medical field. In 1989, of the country's 445 state invention prize winners, 68 or $15 \%$ were women (Beijing Review, Mar. 11-17, 1991) .

Although China's "equal pay for equal work" policy and economic reform have encouraged women to work outside the home, and although the improvement of urban women's educational level has strengthened women's desire to work, the one-child-family policy seems to play a special role in urban women's participation in compensated labor. Without the reduced burden of childbearing and child rearing, women would not have enough time and energy to pursue formal education and special training. Without education and the related change of self-consciousness, urban women would not have the strong desire to become the equal financial partners of men. Nor would they think about further improvement of their social status. Even though the changing world and the current economic reform might finally achieve these, it will surely take a longer time. Therefore the one-child-family policy, together with its associated programs for women, has done the fundamental work of setting urban women free from home, and sending them out to become competitive money-makers in the society. 
THE POLICY AND THE FEMINIST MOVEMENT

Besides helping raise urban women's positions at home and in society, the one-child-family policy also helped start the feminist movement among urban female intellectuals in the 1980 s.

Before the 1980s, most women in China were not very sensitive to the discrimination against them in the workforce and mistreatment in the family. They simply regarded their position at home or in the workplace as an institutionalized legitimacy, and seldom related their mistreatment to the issues of discrimination or the social inequality of women (Croll, 1985). They firmly believed that the establishment of socialism would automatically result in the liberation of women.

Dramatic changes took place, however, in the 1980s. Newly founded women's magazines began to discuss women's problems explicitly. The pages of China Women's News, for instance, were filled with exposes and denunciations of discrimination faced by women. "Feminist outcries" began to appear with some regularity in print (Henig and Hershatter, 1988). This recognition of gender inequality at work and in the family also found expression in the emergence of separate women's organizations: schools, professional societies, and women's studies groups for example. The chinese feminist movement was 
well under way, primarily among the urban female intellectuals.

Then why is it that the feminist consciousness and movement in China occurred in the 1980s, instead of 1970s, $60 s$, or 50s? How and why did it take place at all?

Many analysts suggest that the precondition of this movement is the increasingly explicit and open decade after the end of the cultural Revolution, particularly the economic reforms. Some argue that in the previous years, all work assignments had been centralized, and individual work units did not have any right to hire or fire workers. After 1978, however, much of this system changed. Work units were given the right to select new employees, and to hire and fire. The establishment of private enterprises was encouraged, and industrial companies were made responsible for their own profits and losses. On the one hand, these policies created job opportunities for urban residents, including women. On the other hand, work units used their newly obtained powers to discriminate against women. On the whole, this argument holds that economic reforms had put women into a very difficult situation in the labor market, and that in turn generated the feminist movement.

Other people argue that the feminist movement appeared in the 1980s because of the increasing availability of information about western countries and Western feminist ideas. By then, newspapers and magazines frequently contained 
reports about the lives and problems of women in the United States and Europe, and about feminism and the women's movement in the West. A number of Chinese women who had the opportunity to study in the West applied what they learned of Western feminist ideas to an understanding of their own predicament (Henig and Hershatter, 1988).

Still others suggest that the movement should give thanks to the political liberalization of the post cultural revolution decade in China. They believe that it is political liberalization that made it possible for women to publicly discuss their dissatisfactions, and helped generate the appearance of many women's newspapers and magazines. (China has a state controlled press, and it was only after 1978 that people ventured to produce semi-official or non-official publications.)

In my view, all the above preconditions were necessary for the emergence of China's feminist movement in the 1980s, but the most fundamental precondition was the one-child policy.

Since the implementation of the one-child-family policy in 1979, most women intellectuals have placed much faith in it. They favored the one-child-family policy in that it legally reduced the number of years women must devote to childbearing and child rearing and enabled them to devote time to their own education, career and hobbies. At the same time, however, they disliked the revival of some feudal remnants of 
the oppression of women caused by the population policy. For example, they were very concerned about the reappearance of female infanticide, the increased pressure on girls to leave school early and the uncontrollable wife-battering, etc. These and many other direct consequences of the one-childfamily policy forced intellectual urban women to reconsider their own value in society and at home from women's point of view. Also they were inspired to question the social structures in China and the series of policies imposed by the government.

Why are women discriminated against in the labor market? Why should female intellectuals (academicians and other professionals) retire at age 55 while male intellectuals may continue to work to age 65? Why did Tianjin (one of the biggest cities in China) in 1985 enroll only $3 \%$ women workers and $97 \%$ male workers? Since there has long been a constitution to "protect" women, why should there be so much inequality? Some intellectual urban women felt that it was time for them to do something to express their thoughts, to protest women's inferior social position, and to awaken the consciousness of other women. The open-door policy and the information about the development of an active women's movement in the west helped them realize the options and alternatives.

The discussion in the People's Republic of China of women's issues in the 1980s has been profoundly different from 
earlier discussions in the following ways:

1. The most recent discussion was started and directed by urban women intellectuals and has remained so.

2. The movement has a very clear goal; that is, to improve Chinese women's awareness of themselves and their personal development, to put an end to women's selfcensorship, and to call on society as a whole to alter the context of women's lives. Women are not baby-making machines. They are human beings. As human beings, they must fight for their rights, their interests and their fulfillment (Henig and Hershatter, 1988).

3. Feminist works of fiction appeared for the first time in China's history in the early 1980s. For instance, zhang Jie, one of China's famous women writers, produced a short story in 1982 entitled "The Ark". It is about three divorced women, and was regarded by Western writers as china's first feminist work of fiction (Henig and Hershatter, 1988). One of the first public statements denouncing discrimination toward women was a poem by Wang Fuhua entitled "Four Questions", published in March 1983 in People's Daily. " Each stanza in the poem began with a phrase like "Times have changed; men and women are equal". It is Chairman Mao's phrase, and it has been used by the communist Party to proclaim its success in liberating women after 1949. Therefore, the poet asked "why are men and women not equal?" The poem criticized 
discrimination toward women in almost every sector of society: in pay for agricultural work, factory hiring, college admission, and treatment in the family. Actually wang was one of the first to publicly describe these phenomena as gender inequality (Henig and Hershatter, 1988). This and many other feminist outcries were significant because they expressed the awareness that the status of women was a social problem that remained unresolved.

In short, the feminist movement in the 1980s in China occurred under rather complicated social and historical conditions. The one-child-family policy, no doubt, contributed to the emergence of the consciousness of women's issues. The following section will examine urban women's consciousness of the importance of birth control.

\section{CHANGED ATTITUDES}

In the past few years, with the help of the All-China Women's Federation, a network of family-planning workers has been set up in every city. These family planning workers hand out information on birth control, help women realize the importance of slowing population growth, and inform them of the material rewards for doing so and proper penalties for not doing so (China Today, Mar.1990:26). It seems that this program works especially well in big cities. Nowadays, most of the urban women have realized that the rising population is a 
burden, not a blessing, to the country as a whole, to local areas and to individual families. over-population is a tremendous stumbling block to social and economic development and to the improvement in people's living standards.

What's more fascinating is that many educated urban woman have been organized by the All-China Women's Federation and have left the cities and towns in order to serve the needs of women in poor and remote villages throughout china. Their basic goal is to publicize the government's family planning policy and to ensure that women have rights and opportunities equal to those of men.

The change in marriage and population ideology gives rise to the change in fertility behavior. The old, traditional views on early marriage, early childbearing and several births have been largely replaced by the practices of later marriage and smaller families.

The following tables provide a comparison of urban and rural women on marriage, and fertility behaviors.

First, an urban-rural comparison of the first marriage is presented in Table $V$.

As indicated, in $1987,2,510,339$ urban women got married for the first time. Among those, 1,669,495 women were 23 years old or older (Over 23 is here considered late marriage). The late marriage rate was $66.50 \%$. Compared with the late marriage rate in the countryside, the urban rate was $19.42 \%$ higher. While the number of urban women's late marriages increased by 
92,126 from 1986, the number for rural women decreased by 266,038 .

TABLE V

FIRST MARRIAGE OF CHINESE WOMEN IN 1987

\begin{tabular}{|l|l|l|l|c|}
\hline Regions & $\begin{array}{l}\text { Total No. } \\
\text { Marriage }\end{array}$ & $\begin{array}{l}\text { 23 Yrs or } \\
\text { Older Women }\end{array}$ & $\begin{array}{l}\text { Compare } \\
\text { with } \\
1986\end{array}$ & $\begin{array}{l}\text { Late Marriage } \\
\text { Rate }\end{array}$ \\
\hline Cities & $2,510,339$ & $1,669,495$ & $+92,126$ & $66.50 \%$ \\
\hline Country & $5,044,246$ & $2,374,640$ & $-266,038$ & $47.08 \%$ \\
\hline
\end{tabular}

Source: Pamphlet of China's Population Document by China's Population Research Center in Beijing, Dec. 1988; derived from Tables 7 \& 9, PP291, 293.

As for the birth control rate (See Table VI), urban women's rate is $2.88 \%$ higher than rural women's.

TABLE VI

URBAN \& RURAL WOMEN'S BIRTH CONTROL RATE BY METHOD IN 1987

\begin{tabular}{||l|l|l|l|l|}
\hline Region & $\begin{array}{c}\text { Hysterectomy } \\
\text { Users }\end{array}$ & $\begin{array}{l}\text { IUD } \\
\text { Users }\end{array}$ & $\begin{array}{l}\text { Other } \\
\text { Method } \\
\text { Users }\end{array}$ & $\begin{array}{l}\text { Total Birth } \\
\text { Control } \\
\text { Rate }\end{array}$ \\
\hline Cities & $10,224,196$ & $17,219,673$ & 623,590 & $88.67 \%$ \\
\hline Country & $33,889,580$ & $33,332,992$ & 394,707 & $85.97 \%$ \\
\hline
\end{tabular}

Source: Pamphlet of China's Population Document by China's Population Research Center in Beijing, Dec. 1988; derived from Tables $15 \& 17 ; \mathrm{P} 299 \& \mathrm{P} 301$.

Table VII shows that in 1987 the unplanned birth rate for urban women was $9.25 \%$, while the rate was $20.61 \%$ for rural 
women. Another indicator that suggests a different attitude between rural and urban women is a comparison of the percentage of those who obtain one-child-certificates (See Table VIII).

TABLE VII

UNPLANNED BIRTHS IN 1987

\begin{tabular}{||l|l|l|l||}
\hline \hline Regions & $\begin{array}{l}\text { Total No. } \\
\text { of Birth }\end{array}$ & No. Unplanned & $\begin{array}{l}\text { Unplanned } \\
\text { Birth }\end{array}$ \\
\hline All Cities & $3,451,833$ & 319,212 & $9.25 \%$ \\
\hline Countryside & $9,905,697$ & $2,041,540$ & $20.61 \%$ \\
\hline
\end{tabular}

Source: Pamphlet of China's Population Document by China's Population Research Center in Beijing, Dec. 1988; derived from Tables 27 \& 29.

By the end of $1987,32.3$ million women overall got a onechild-certificate, an increase of 1.8 million over 1986. (Chinese Population Yearbook 1988:280) If we study the data by urban-rural region, however, we find that the situation is uneven. Table VIII indicates that more than 2,210,765 urban women in 1987 than in 1986 claimed the one child certificates; the rate increased $1.26 \%$. On the other hand, the number of rural women claiming the certificates in 1987 dropped $1,137,816$ from the year before, and the claiming rate was $25.28 \%$ lower than that of urban women.

It appears that it is much easier to carry out the onechild-family policy in the cities than in the countryside. 
Evidence also show that urban women react to the policy with a more active and positive attitude than their rural counterparts. But why are urban women more willing to accept the one-child-family policy than rural women? What are the existing preconditions for the achievements of the one-childfamily policy among urban women?

\section{TABLE VIII}

NUMBER AND RATE OF WOMEN GETTING ONE-CHILDCERTIFICATES IN 1987

\begin{tabular}{||l|l|c|c|l||}
\hline Regions & $\begin{array}{l}\text { Total No. } \\
\text { Certificates }\end{array}$ & $\begin{array}{c}\text { Compare with } \\
1986\end{array}$ & $\begin{array}{c}\text { Rate } \\
\%\end{array}$ & $\begin{array}{l}\text { Compare } \\
\text { with 1986 }\end{array}$ \\
\hline All Cities & $15,116,922$ & $+2,210,765$ & $35.96 \%$ & $+1.26 \%$ \\
\hline Country & $10,755,338$ & $-1,137,816$ & $10.68 \%$ & $-0.44 \%$ \\
\hline
\end{tabular}

Source: Pamphlet of China's Population Document by China's Population Research Center in Beijing, Dec. 1988; derived from Tables 11 \& 13, PP295\& 297.

INCENTIVES FOR YOUNG MOTHERS

Major factors that inspire urban women to have only one child are the various incentives offered by the government and the improved health care for young mothers and their babies. The following are the most popular rewards and chief health care programs that are available for urban women (Kane, 1985). The first program worth mentioning here is the development of a modern health-care network. Like a protective 
umbrella, this network aims at protecting both mother and her child from the very beginning of a woman's pregnancy.

Usually, when a "planned" pregnancy is confirmed, the woman may join the health care program by showing the "authorization" paper to the relevant doctor. Then she receives a card outlining the antenatal checkups required and a notebook to be used in recording her physical condition, the development of the unborn baby and the postnatal health of both mother and baby. She will be advised to read certain books about pregnancy, nursing and raising an infant.

During her pregnancy, the woman receives free antenatal examinations in the third, fifth, sixth and eighth months. More frequent examinations will be conducted if there is any problem. Medical workers will give advice on appropriate activities, work and rest, and what kind and amount of physical work one can do. Guidance is also provided as to personal hygiene, diet and dress during pregnancy, and the way to avoid disease and minimize the risk of harm from radiation and certain medicines. The aim of this program is a troublefree pregnancy and delivery of a healthy baby.

The introduction of the provision of a paid maternity leave only for the first child also plays an important part in encouraging urban women to become parents, but only once. The mothers of first borns can have three months paid maternity leave as soon as they give birth. Women no longer have to choose between working and having a child. In order to 
overcome the concern of some women about entrusting their precious only child to outside care after the first three months, an alternative offer has been developed in some areas, that is, the extended maternity leave. A factory in Shanghai, for instance, "offers one year's maternity leave to single child mothers, granting full pay and an assurance that neither their promotion prospects nor wage increases will be jeopardized as a result" (Kane, 1985). Some textile mills in Henan Province offer a three-year-maternity leave to singlechild mothers, with $60 \%$ of pay per month (Women of China, 1991) .

Through such policies, urban women are given the choice of looking after their only child themselves.

The increasingly improved day-care centers and cooperative child care arrangements make it possible for working mothers to go back to work after their maternity leave. This, in turn, encourages their working units to give them further training and career development. With a job to go back to, the fact that childbearing is the only future for married women is no longer true.

Additionally, there is a rapid development of the associated service facilities in the cities, such as laundries, sewing and clothes-mending shops and repair shops for household equipment. These and many other public services help lighten the burdens of urban women. Even though most of them have to work eight hours a day, six days a week, their 
lives have been made much easier than their mothers' generation.

Another factor that helps form the small family norm is the pension system in cities. If you work in a state-owned company, you can get a pension after you retire. Women are not excluded. Exactly like men, a woman can get $80 \%$ of her previous salary after she is retired if she has worked in state industry for over 30 years. Otherwise, she gets $60 \%, 40 \%$ or less, depending on how long she has worked in a certain working unit. In some cities, childless women can get pensions of $100 \%$ of their previous salary (Xinhua, 10 July 1979, and 7 Nov. 1979, in Chinese).

Given this situation, children born to urban families have lost some of their value to their parents as a long-term investment for security in old age. Beside, bringing up a child in the cities is much more expensive than in the countryside. According to 1986 statistics, it costs 6,600 yuan (about $\$ 1320$ ) to raise a child to the age of 16 in the countryside, while in urban areas it costs 18,740 yuan (about \$6148) (Deng, 1989). I remember hearing a lot of complaints from my friends and colleagues about the money they spend on their children. Usually an urban child uses about one third or even half of the family salary because he/she needs care, food, clothing, and education. Unlike children in the countryside, children in the cities cannot be much help to their families when they are young. 
Since the average monthly salary of an urban woman is about $\$ 40$ only (Hou, 1991), it is almost impossible to have any surplus left after all the expenses are paid. If you plan to have a child, your standard of living will most likely be lowered. Therefore, it requires serious consideration for an urban couple to decide to have even one child.

Priority of housing is another vital attraction to urban women.

Due to the longer life span (The average life span rose from 35 years in 1949 , to 50 years in the 60 s, to 69 years in 1987), ${ }^{12}$ and a great increase in the urban population in the past ten years, housing has become a big problem in China's cities. According to the household survey in 1987, the average space for an urban resident is only 3.8 square meters, while a rural resident may have as many as 16 square meters. ${ }^{13}$ Therefore it is not uncommon in cities to see two or even three generations living under one roof. This situation can lead to some family conflicts and inconveniences.

Population control planners are aware of this problem. In order to encourage urban women to accept the one-child-family policy, they promise these women housing priority. That is, if a woman stops at her first birth and claims the one-child certificate, her working unit is responsible to arrange for an

12 See Hou Ruili's article, "China's Population Issues", an interview with Peng Pei-yun, the Minister of the state Family Planning Commission, China Today, Aug., 91, PP28-30.

13 See Chinese Population Yearbook, 1988. 
apartment for her family. This is an important bonus to urban residents, especially to those women who are trying to escape their mothers-in-law!

other incentives like priority for the only child to get medical care, to go to better schools, to be given an extra 510 yuan per month until he/she is 14 , are all attractive to urban women. The single child also has priority in job allocation (e.g. Xinhua, 7 Nov. 1979 in Chinese). This has greatly reduced the fears of parents that their only daughter will not get the beneficial state job because of discrimination against women in some working units.

The above are the major factors that motivate urban women to accept the one-child-family policy.

But what are the special factors that affect rural women in their attitudes toward the one-child-family policy? What kind of unique situations are they in? Are they happy about the policy? The following chapter will explore the possible answers. 
CHAPTER VI

IMPLICATIONS OF THE POLICY FOR RURAL WOMEN

Although the one-child-family policy has some potential beneficial outcomes for women, and has worked out quite well in cities, the consequences of this policy for rural women are not so good. Women in rural areas remain more traditionally bound by cultural and familial expectations. Generally speaking, the policy negatively affects rural women's labor, social, health and family status. These negative impacts can be seen by examining the sensitive position of women at home, the forced abortions perpetrated by government officials, the increases in female infanticide and wife-abandonment, and an increased pressure on girls to leave school early. This chapter will examine each of these effects.

\section{UNIVERSAL PREFERENCE FOR SONS}

Usually, a rural woman's position in a family is determined by the sex of the child she delivers. When a boy is born, the family will have some kind of celebration, say distributing red eggs, inviting relatives to enjoy "happy noodles", or having a banquet in a restaurant. And in most 
cases, the mother's position in the family is automatically raised, because she has made a "great contribution" to carry on the family line. In contrast, if a woman gives birth to a girl, there is generally no celebration, no party, no friends. Instead the lying-in woman may have a bad time --- she might be scolded by her mother-in-law, beaten by her husband, and sometimes even divorced by her husband. The situation becomes even more serious in the countryside now that china is carrying out the one-child-family policy.

Why are boys more desired than girls? In order to answer this question, it is necessary to go back to the traditional attitude of "the more children, the better", and the strong emphasis on having a son to carry on the family name. In old China, the child mortality rates were very high (The infant mortality rate dropped from $20 \%$ in 1949 to $4 \%$ in the $1980 \mathrm{~s}^{14}$ ) and aged parents were mostly dependent on their sons for support. Actually, there has been a universal preference for sons in China for centuries. Sons continued the family line; upon marriage they brought their wives to live in the parental household and supported the older generation, and finally they tended the ancestral shrines. As a typical example of this expectation, the birth of a boy in preliberation china was usually celebrated as the arrival of a scholar who would lead the family to prosperity. But when a girl was born, she was considered no more important than a future operator of the 
family spinning-wheel. Although improved medical care today has brought about a notable decrease of the infant death rate, some old ideas are hard to change. In the countryside, care of the elderly is still a family responsibility by custom. And to many peasants, the son is still the most reliable person, especially when parents are getting old. They consider a daughter only as a kind of parasitic being. When she is young, she depends on her parents; when she grows up and gets married, she depends on her husband. Traditionally she cannot carry on the family line, nor can she take care of her aged parents, because as soon as she gets married, she will join her husband's family, and become permanently separated from her own. Therefore, the parents often feel quite disappointed because the investment they put out to bring her up will never come back to them.

In addition to the influence of the old traditional ideas, some practical problems have worsened the situation. In cities, most factory and official workers have regular pensions when they are retired, but not the peasants in the countryside. So when rural workers are too old to work in the fields, they have to ask their children to take care of them, and according to tradition, they will ask sons instead of daughters. Besides, the New Agricultural Policy has assigned cultivated land to each family, and in order to plough the farmland, peasants need more hands, especially a strong labor force. In this way, some contradictions emerge directly from 
the problems of the new state policies. The family responsibility system encourages peasants' agricultural production, but the one-child-family policy prohibits the traditional rural strategy from increasing family labor power and income, traditionally accomplished by having many children, including several sons.

As a result of the current production system and the traditional beliefs, many farmers in china still prefer large families with several sons. So in order to have more children and more sons, people have tried various methods to circumvent the one-child-family policy. In their desire to have sons, some couples even kill their baby girls through neglect or murder, a form of violence which has begun to draw more and more attention from the government.

\section{FEMALE INFANTICIDE}

Actually, female infanticide is not new in china. For centuries, it was always daughters who were sacrificed whenever there was competition for scarce resources. Usually female infanticide was practiced throughout China directly by intervention at birth. And indirectly it was practiced as a result of the malnutrition and sickness from which girls suffered disproportionately because of the unequal distribution of family food and medical attention. One local study of a village revealed that in the first five years of 
life the boys outnumbered the girls in proportion of 100 to 35 (Croll, 1985). Of course, this was an exceptional situation. However, without accurate data on the sex ratio at birth in the past, it has been impossible to measure the scale of female infanticide. Data from Beijing in 1917 show that the female mortality rate in the first year of life was nearly $30 \%$ higher than that of males. The death rate of females from 1 to 5 years of age was 152 per 1000 and for males 122 per 1000 . To some extent, this indicates that the neglect is strong (Croll, 1985). Female infanticide used to be so widespread in China, especially in remote and destitute places, that its serious consequences are still felt today. For example, in Huaiyuan County, Anhui Province, quite a few male villagers over 40 years old are unable to find female partners and get married (Beijing Review, No.5 Jan.31, 1983 P4).

The Chinese people abolished the rural feudal system during the Land Reform Movement shortly after the birth of the People's Republic of China in 1949. As a result, the people's livelihood improved remarkably. Women increasingly joined men in productive labor and won greater respect from society. For many years female infanticide was not heard of (Beijing Review, No5, Jan.31,1983:4).

The feudal idea of favoring boys over girls, however, is not completely gone. Some couples feel unfulfilled if they do not have a son. And a woman's failure to produce a male child to carry on the family line is still condemned, and sometimes 
regarded as the greatest impiety. Thus some couples go on having children until a son is produced. This explains why a great number of rural families have more than two children, especially if the first two are daughters.

The problem was complicated by the nation's population policy in 1979, which turns out to be a challenge for those who desire sons to carry forward their family lines.

Since the one-child-family-policy allows each couple to have only one child, some people sell, desert or even kill their female babies in order to preserve their option of having a son. The exact figures of female infanticide are unknown, but there are indications that it may not be a rare occurrence. For instance, in some rural areas the ratio of boys to girls is 5 to 1 , People's Daily reported in April 1983 (The oregonian, sept. 26,91 ). In the eastern district of Hefei city in Anhui it was reported that at least 50 baby girls were drowned within a period of two months after the new population policy was implemented. This must have contributed to the unbalanced sex ratio of 112.45 to 100 among newborn babies in Anhui in 1981 (Beijing Review, 2 May 1983, P13). Li Chengrui, Director of the state statistics Bureau also admitted that cases of drowning and abandoning female babies have been found in some areas (Ibid). Former Premier Zhao Ziyang's condemnation of infanticide at the Fifth session of the Fifth National People's Congress would also suggest that the practice is of national concern (The China Quarterly, 
1984). Additionally, data released from China's 1990 census show a suspiciously high ratio of boys over girls in reported birth: 111.3 boys for every 100 girls. By some statistics, more than 600,000 baby girls (Oregonian, 91) who ought to be there, are not. They have simply disappeared. They were not reported in the 1990 census.

Where are the baby girls?

We know that the normal sex ratio throughout the world is about 105 or 106 boys to 100 girls. Evidence has shown that China, too, has a normal sex ratio (See Figure 2.)

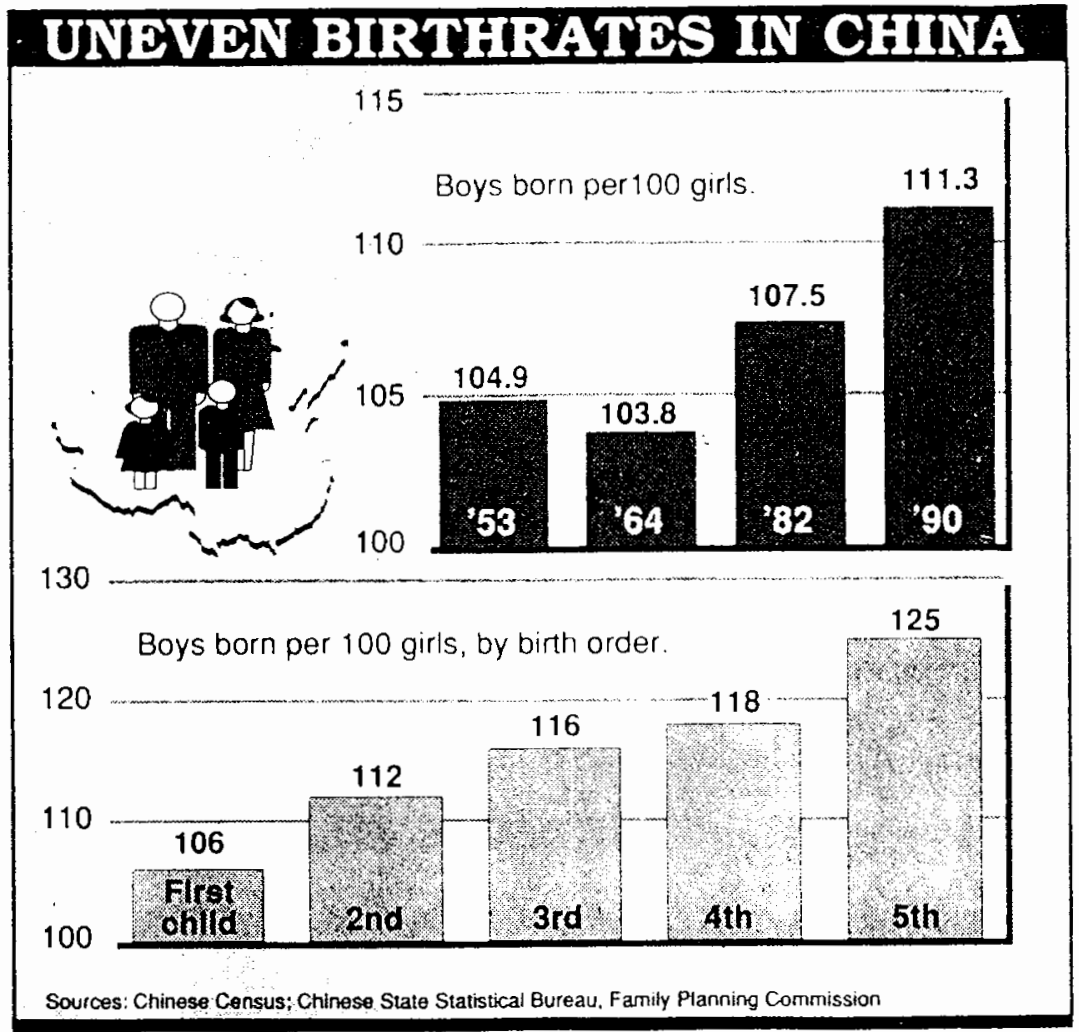

Figure 2. Uneven Birthrates in China. Source: The Sunday Oregonian, June 23, 1991, A14. 
From the only four census counts ever done in China, we can see that the sex ratio for newborn infants in the 1953 census was 104.9 to 100 , and in the 1964 census it was 103.8 to 100 . It was only beginning with the 1982 census, three years after the one-child-family policy was implemented, that the ratio changed noticeably. Two surveys done in 1987 and 1989 respectively show an increasingly high sex ratio. The 1987 survey found 110.5 boys to 100 girls, while the 1989 survey found 112.5 boys to $100 \mathrm{girls}$ (Oregonian June 23, 91). Therefore, the sex ratio disparity shown in the 1990 census was not a fluke.

As previously mentioned, female infanticide was common in pre-1949 China. But after 1949 it seemed to disappear, until recently. In the past, peasants who sought to survive in a competitive system of private landownership committed the crime and had to bear most of the moral responsibility themselves. But now peasants may place part of the blame on the government for limiting their freedom of choice to such an extent that they are being forced to kill their own flesh and blood (Wong siu-lun, 1984). "We cultivate our own land, eat our own grain and bring up all our children on our own. We have taken responsibility of the land and there is no need for you to bother about our child birth", some peasants said. And more and more complaints like this keep appearing (Wong, 1984). 


\section{WIFE-BEATING AND WIFE-ABANDONMENT}

A related topic regarding the birth of the so-called "wrong" sex is wife-battering and wife-abandonment.

There is scientific evidence that the sex of a fetus is not determined by the mother. Yet in their great desire to have sons, some men torment and desert their wives after they give birth to daughters.

Since the announcement of the one-child-family policy in 1979, the incidence of families' punishing women for "wrong" reproductive results has increased substantially in the countryside, although it is impossible to know how frequently it occurs. The chinese press has been publicizing and protesting cases of familial abuse. And a common explanation offered for wife-battering recently is the failure of a woman to bear male offspring. In 1982, the Women's Federation of Shenyang, Liaoning Province, reported that local cases of maltreatment of women who gave birth to girls were on the rise: twenty cases had been reported in the first half of the year, in contrast to almost none a year before. And there are even more divorce cases associated with production of the wrong (female) sex.(Henig and Hershatter, 1988). When a woman does not produce sons after having had several daughters, or if she does not want to disobey the birth-control policy, she is frequently shunned or dismissed by her husband's family. 
Some husbands simply divorce their wives in order to marry other women and produce sons. Some commentators recognized this phenomenon as an unintended result of the one-childfamily policy (Zhongguo Qingnian Bao, 1982).

The negative impact on the life of the abandoned women is obvious and great. First of all, they are ridiculed or looked down upon by the people around them, because they have been "deserted" by their husbands.

Second, they run into serious economic problems. Because they depended on their husbands and do not have any remarkable skills, they have to toil in the fields like men, especially in the situation of the new agricultural policy. And abandoned women often have one or two daughters. In order to help support the family, the little girls are often forced to leave school and do housework or work in the fields with their mothers at an early age. According to statistics, "83\% of the 7.2 million children who drop out of school are girls", girls in the countryside (Women of China, 1990, Mar. P2). In the long run, this situation is likely to produce a high number of illiterate rural women. And low levels of education will most likely have a direct effect on fertility rates. In fact, in some remote areas, there is already a vicious cycle of ignorance followed by too many children, followed by poverty, followed by greater ignorance ---- which again leads to too many children and more poverty.

Third, these abandoned women lack self-confidence, and 
often do not have the courage to interact with people freely. They cannot see any hope for their future, nor can they play an active role in overcoming poverty in their families. They are lonely, isolated and disassociated. Some of them truly become social outcasts. A special report on this subject can be found in Lu Yin's article in China Today, 1990.

The promising sign is that the government has realized the seriousness of wife-battering and wife-abandonment, and since 1983, the All China Women's Federation has taken up the issue of protecting the legal rights of women in those domains.

From the time the Communist Party took power in 1949, the ACWF has been the official and exclusive organization representing women. As long as the Women's Federation exists, government policy-makers apparently assume, women's interests are supposed to be protected and there is no need to form other organizations within, or independent of, the government. Like many other mass organizations, the Women's Federation was inactive during the cultural Revolution, and reorganized only in 1979. During the early 1980's the primary function of the Women's Federation was to mobilize women to participate in government-sponsored political campaigns, rather than to represent the interests of women to the government. It was only in 1983, four years after the implementation of the onechild-family policy, that the ACWF began to take action to protect women. By then, the issue of wife-battering and wife- 
abandonment had become an issue that could no longer be neglected.

In April, 1983, the secretariat of the Central Committee of the chinese communist party decided to make "protecting the legal rights of women and children" a major component of Women's Federation's work. Local branches of the Women's Federation responded with a number of innovative institutional measures. In one Shanxi county, the Women's Federation and other local organizations in 1985 set up a "letter and visit network for women's problems" with branches in every village, to take complaints from women about parental interference in marriage choice and maltreatment. Village women no longer had to leave their home communities to voice their grievances. The purpose of the network was to resolve problems through mediation before legal action became necessary.

The heart of the Women's Federation work, however, is intervention by dedicated local women cadres who want to see justice done. In one rural Liaoning case, for instance, Women's Federation cadres learned of a woman who had been maltreated by her husband for six years. When she demanded a divorce in June, 1984, he cut out her tongue. The Women's Federation conducted an investigation, provided information to the Party and government organs, and saw that the case was publicized in the press. Their efforts resulted in the man's trial and execution for causing grievous injury to his wife (Renmin Ribao, Jan. 7, 1984:7). 
In another case in 1981, a cadre of the Women's Federation of Nantong county, Jiangsu province, off on a business trip, heard of an outrageous incident. Peasant woman Chen Mei had a husband who was working away from home. Her father-in-law and brother-in-law suspected her of improper sexual conduct and beat her badly. They broke three of her ribs and punctured a lung. They would not let chen Mei go to the hospital for treatment. They also persuaded a local cadre to threaten her not to tell anyone, and they kept her schoolage child locked up at home. only on the third day, when someone from Chen's natal family arrived, did they send her to the hospital.

When the Women's Federation cadre heard of this incident, one of the members hurried to the hospital, comforted chen Mei, and said to her, "The Women's Federation will back you up." This cadre, along with the party committee and the Women's Federation of the commune, investigated the incident and made arrangements for Chen Mei's medical treatment and a place to live. The cadre immediately reported the incident to the county Party committee. The county Women's Federation and the police conducted a joint investigation, and the assailants were punished in accordance with the law. At the court session where judgment was pronounced, the member of the cadre from the county Women's Federation said, "The Women's Federation speaks up for battered and abused women, and protects their legal rights and interests" (Zhongguo Funu, Jan.1981:44). 
Although the movement to protect the legal rights of Chinese women still has a long way to go, the increased public attention to a strong legal system and the various efforts made to control gender violence are important steps in the move to the final elimination of violence against women.

\section{"FLOATING POPULATION"}

Another phenomenon associated with the one-child-family policy is rural women's joining the "floating" population with their husbands (China Today, 1991). That is, they wander from place to place, migrate to cities without proper residence permits, and deliberately seek to avoid pressure to use birth control because they want large families or want a son after having had several daughters. There are three frequently used patterns:

1. The woman leaves her hometown with her husband shortly after they get married. They live in one city or town for a while and then move to another one. The husband does all kinds of temporary jobs to support the family, while the wife stays in their humble home, giving birth to children. After they fulfil their reproductive plan, they return to their hometown.

2. The couple already has a daughter, and wants a son. They leave their young daughter in the care of her grandparents, and wander wherever they can, until they give birth to a son. 
3. After a woman gets pregnant, she is sent to a relative's home far from her own village. If the new-born is a son, she will come back happily. otherwise, she will leave the infant girl with her relative, or simply desert her in order to come back home and get pregnant again.

By "floating" they not only avoid the authorized "birth quota", but also escape successfully the expensive fine for giving birth to more than one child.

According to some statistics, the floating population has risen to 50 million. By 1989 , it was said that:

Almost all of them (the floating population) have at least two children; some even have three or four. They buy grain and coal at negotiated prices, do not have a permanent job, and do not belong to any unit. They work hard to earn as much money as they can, and they can have as many children as they want. They form a social group that is virtually subject to no one's jurisdiction and thereby poses a serious threat to family planning efforts (Aird, 1990).

These "floating" rural couples are very difficult for government officials to follow and tabulate. And given the difficulties of monitoring this group and effectively implementing family planning, these couples have produced a large number of over-large families. A 40-year-old farmer from Hanyang district in wuhan ${ }^{15}$ has recently been found to have eleven children, five boys and six girls (Deng, 1989) . Eighty rural families are now seeking temporary jobs in this

15 Wuhan is a large and important industrial city in china. It is also the capital of Hunan Province, which is located in Southern China. 
district. These people already have two or more children, and they have given birth to a further twenty children since their arrival (Deng, 1989). A recent study shows that some 3 million babies born in 1987, and 1 million in 1988 were unauthorized third or fourth children. And around 2.5 million people married below the legal age, putting them in the position to give birth at a relatively early age (Hu, 1989).

Besides the extra burdens the "floating population" has added to the country, the "floating" women have many problems and difficulties. The most common one is that they cannot get proper medical treatment during pregnancy and even during delivery. As mentioned before, chinese women are expected to have official authorization to become pregnant. When they are pregnant without permission, they are unable to get prenatal care because they lack authorization papers to present to local health clinics (Chen, 1985; Weisskopf, 1985). As a result, the "floating" mothers and their babies often suffer from malnutrition, and the health of the new-born babies is negatively affected.

Nevertheless, a number of rural women still prefer to join the "floating population" than to stay at home. The obvious reason is that they can have as many children as they want. Meanwhile they can avoid the reproduction coercion from the government. 


\section{BIRTH CONTROL AND RURAL WOMEN}

The fertility decline among rural women has been the result of a determined and successful birth planning program. And an inseparable part of the program is the prevailing use of contraceptives in the countryside. Since the late 1970s, various contraceptive instruments have been gradually introduced to the countryside, and more and more rural women have started using them. Although considerable achievement has been made, birth control in the countryside still has several common problems which affect rural women:

1. IUDs, abortions and sterilizations are the most common contraceptives used in the rural areas. And the practice of birth control is primarily considered to be the responsibility of married women ---- a responsibility arising from their sex role as bearers of children; it is women who get abortions; It is women who use IUDs, and it is usually women who are sterilized. Under the one-child-family policy, rural families show a greater preference for sterilizing a daughter-in-law rather than a son. Patriarchal families also prefer female sterilization because they value men and do not want to put them at risk. If things go on like this, husbands and in-laws of sterilized women may press for divorce in order to try to get grandsons by a second wife. In fact, some people have already applied this divorce strategy as a possible 
alternative if the first-born child is a girl. In addition, some sterilized women suffer form "sideaches" (internal infections) and lose their ability to work; some of them even lose their lives (Dalsimera and Nisonoff, 1987). The seriousness of the problem can be sensed by listening to Li Lianxin's ${ }^{16}$ concerns: "What I'm most worried about is that something may go wrong during the vas sterilization owing to the poorly-equipped rural clinics," she says. "No economic compensation can counteract side effect or loss of life..." (Women of China, Sept.1989).

2. As previously mentioned, $53 \%$ of the rural women rely on IUDs. And once a woman has had the IUD inserted, she is unable, and does not have the freedom or right, to take it out.

The most-widely used IUD in China is a modified ota made of stainless steel. It has no string on it and, therefore, can only be removed by a trained medical person with a fine metal hook. Also, files on women's method of contraception are kept, and women are required to receive regular examinations to make sure that their coils are in place and no "unplanned" pregnancies have occurred. Usually, doctors and nurses are not allowed to remove IUDs from any woman without official authorization. Those who have done so without permission from an associated birth-control official will be punished. In the

${ }^{16} \mathrm{Li}$ Lian-xin is a woman cadre member in Yuncheng county, Shanxi Province. 
past few years, many cases have been published in newspapers and magazines, criticizing doctors and nurses who have unofficially removed IUDs.

3. In some poor and remote areas, forced abortions are still very common.

In theory, the nationwide birth control programs have made all contraceptive methods available to married couples. In practice, only the urban women have options to choose different birth control methods, and to get contraceptives free from a nationwide contraceptive distribution network. In some rural areas, it is still difficult for women to get contraceptive devices. And in some other areas, abortions are the only available method for women. Dalsimer and Nisonoff in 1982 mentioned in their article that "extreme measures like sequestration of pregnant women to convince them to abort and arrests by Public security officials, the women sometimes are bound and transported in animal cages, followed by late abortions". ${ }^{17}$ Even Peng Peiyun, minister of the state Family Planning Commission, admitted that "some abortions on women in the later stages of pregnancies do occur in remote areas" (Beijing Review, Mar. 91, P29).

4. Handing out fines has proved to be useless in the past few years.

17 Also see John Gittings, "Communes: New Directions or Abandonment? China Now, No. 102 (May/June, 1982; and Aird in particular, emphasizes the coercions of women which result form the one-child-family policy. 
As previously mentioned, since 1979, there has been no national law to guarantee the implementation of the one-childfamily policy. Therefore various local measures have come into effect. One of the most common methods of control in the countryside is fining, but recently it has ceased to be effective. In the first few years of the one-child-family policy, parents of an unplanned second birth were fined 2,000 to 3,000 yuan (approximately a yearly salary of a university professor), which was a shocking figure for most of the peasants. In the past few years, however, because of the responsibility system and economic reform, many getting-richquick farmers have emerged. These newly-rich farmers are not at all afraid of being fined. (See Figure 3.)

As for the poor families, they simply open their doors to the birth control workers and tell them to take whatever they like (Xiao and Chen, 1989). To these poor families, the potential labor productivity of sons can ultimately reduce economic disincentives imposed by the government.

"The situation in the countryside is different from that in the cities," Pei Yingping, a woman cadre member, says. "It is true that the more sons you have, the quicker your family becomes well-off. And no farmer does not wish to earn more money as soon as possible" (Xiao \& Yan, 1989).

One might ask: for whom are children born? Who wants more children and who wants fewer and why? The interests of the state and of private families are not necessarily the same; 
nor are the interests of the mother, the father, and the grandparents the same. Women bear the burden of retribution from the government when they bear an extra child, and in rural areas from their families when they bear a female child. As Wolf states: "If a woman's husband and his family decide that it is worth the economic risk, it is her body that must conceal the illegal pregnancy, her body that will be the target of the cadre's anger if its quota is exceeded, her body that will endure a forced abortion perhaps too late to be entirely safe" (Wolf, 1985). 


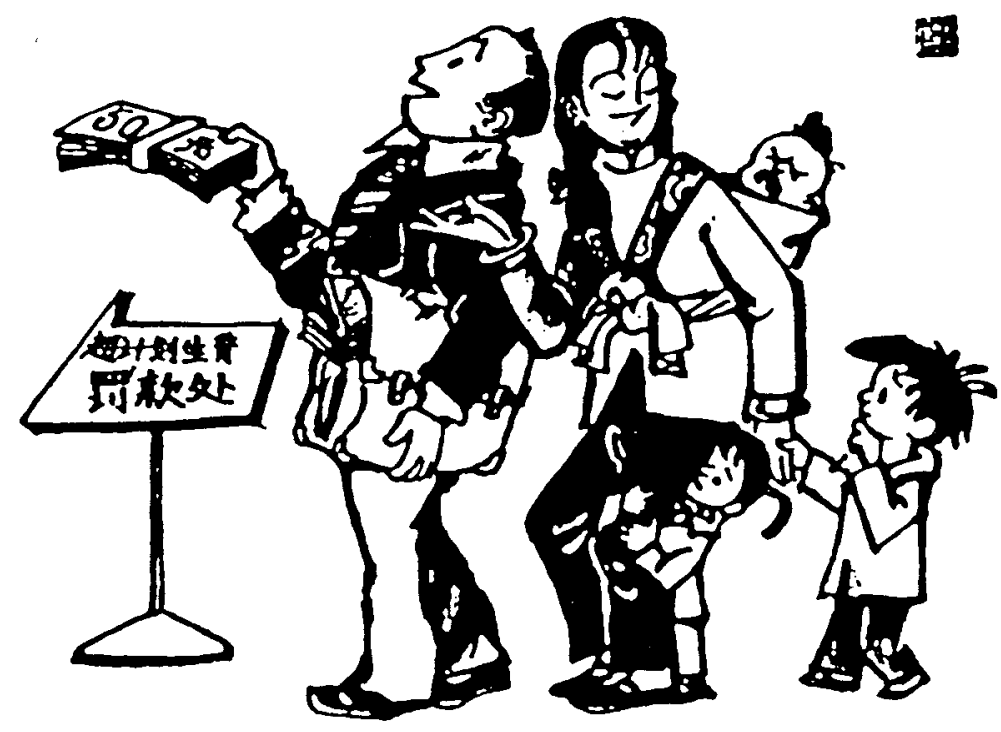

"Don't be afraid, klds. Your dad has enough money to pay the fine." The sign says: A fine will be imposed for having extra children.

Chang Tiejun

Figure 3. Cartoon. Source: China Reconstructs XXXVIII, No.7, July 1989, P31. 
CHAPTER VII

CONCLUSION

The purpose of this study is to explore the implications of the one-child-family policy for chinese women. Various kinds of descriptive data have been applied to analyze the positive and negative impacts of the policy on both urban and rural women in China. The results of the study have confirmed the two hypotheses advanced at the beginning of the thesis.

This study shows that since the implementation of the one-child-family policy, Chinese women's age at first marriage has increased; years women spend in childbearing and child rearing have decreased; the percent of women of childbearing age who use contraceptives has increased.

This study also shows that urban women are more willing to accept this government policy because they benefit more from the policy than their rural counterparts. For example, since the implementation of the one-child-family policy, there has been a great increase in social services and medical care programs for young mothers in the cities. The reduced number of years spent on childbearing and child rearing has enabled urban women to participate in their education improvement, working outside home, and various social movements. Above all, 
urban women's attitude toward the gender of the only child has changed. To many women now, a baby girl is as acceptable as a baby boy .

Compared with urban women, rural women in China seem to be negatively affected by the one-child-family policy more than they are compatible with it. Instead of getting all the benefits urban women have received from the one-child-family policy, rural women's labor, social, health, and family status has been negatively affected: female infanticide reappears; wife-beating and wife-abandonment increase; "floating population" emerges. The thesis also discusses the birthcontrol problems with rural women and the pressure they feel from their families' desire of having sons.

The findings of this study show that so long as the onechild-family policy remains, the differential responses of rural and urban women are likely to remain. So long as rural women's personal goals remain unfulfilled, the problem will continue.

The findings of the study also reveal a very serious problem with the one-child-family in rural China. That is, although the policy reduces China's population rapidly, it damages rural women's lives. Furthermore, it will surely damage the future generations of all chinese women, especially rural women if the policy is extended into future decades.

According to some reports, Chinese government plans to carry on the one-child-family policy for another ninety years 
73

in order to reduce the total population to the ideal number -- 700 million. NINETY YEARS! What will happen to China's females ninety years later if the current problems remain? This and many other problems definitely need to be further tackled and studied. But one thing is clear: the one-childfamily policy is not the best solution to raise Chinese women's status or to protect women. To me, the policy can only be regarded as a kind of "transitional resolution" (one of the conflict resolutions offered by conflict theorists in sociology). It will not lead to permanent termination of the current population problems China has now, but it does facilitate temporary reduction so that more permanent conciliatory structures and solutions may be developed and maintained. 
REFERENCES

Aird, John S. 1990. Slaughter of the Innocents, The AEI Press, Washington D.C.

Beijing Review 1990. "China's Population down to size" oct. $15-21,8-10$.

Chen, Pi-chao, 1985. "Birth Control Methods and organization in China", China's one Child Family Policy, edited by Elizabeth Croll, st. Martin's Press, New York.

Chinese Population Yearbook 1988. China's General Population Research Center.

Coale, A. J. 1981. "Population Trends, Population Policy \& Population studies in China", population and Development Review, Vol. 7, No 1, P79.

Dalsimer, Marlyn and Nisonoff, Laurie, 1987. "The Implications of the New Agricultural and One-childfamily Policies for Rural Chinese Women", Feminist Studies, 13,3,fall, PP583-607.

Davin, Delia 1985. "The Single Child Family Policy in the Countryside", China's one Child Family Policy, edited by Elizabeth Croll, st. Martin's Press, New York.

Davis-Friedmann, Deborah 1983. Lonely Lives: Chinese Elderly \& the Communist Revolution, Harvard University Press, Harvard.

Deng, Shu-lin, 1989. "Sounding the Alarm on Population Growth", China Reconstructs, July, PP30-33.

Dong, Yuguo 1989. "Controlling in Birth Rate," Beijing Review, April 24-30.

Etzioni, Amitai 1961. A Comparative Analysis of Complex organizations, Free Press, New York.

Farr, Kathryn A., 1990. "Sociology of Women", lecture notes. 
Fox, Mary Frank, 1989. "Women and Higher Education: Gender Differences in the status of students and Scholars" PP.217-235, Women: A Feminist Perspective, 4th Ed., Edited by Jo Freeman, Mountain View, California, Mayfield.

Henig, Emily; Hershatter, Gail 1988. Personal Voices ---Chinese Women in the 1980s. Stanford University Press, Stanford, California.

Hou, Ruili, 1991. "China's Population Issues", China Today, North American Edition, China Books \& Periodicals, Inc. San Francisco, Vol XXXX No.8, August 28-30.

Hu, Xue-pin, 1989. "Birth Control Problem in the Countryside and Its Measures"; in Chinese; Population Research Center, Henan Province, Henan University, Henan, China.

Huang, Wei, 1990. "Chinese Women: Active in Society" Beijing Review, Nov. 24-27.

Ishikawa, Shikawa 1983. "China's Economic Growth Since 1949 -- an Assessment", China Quarterly June, P262.

Kane, Penny, 1985. "The single child Family Policy in the cities", China's one Child Family Policy, edited by Elizabeth Croll, st. Martin's Press, New York.

Kang, Jun, 1989. "What Makes Women Work Outside the Home?", Women of China, June, P43.

Li, Bohua and Freedman, Ronald, 1990. "The Rise in Female Education in China: National and Regional Patterns", The China Quarterly, Mar., PP61-93.

Li, Choh-ming 1962. The statistical system of Communist China, University of California Press, Berkeley.

Liu, Zheng 1982. "Population Planning in China", China Reconstructs, Feb. 24-25.

Lu, Yin, 1990. "Women Helping Women: Economic Independence Spells Dignity", China Today, Mar., PP17-20.

O'Hara, Albert Richard 1972. "The Position of women in China". Journal of the China Society. Vol. 9, 77-85.

Porter, Jack Nusan,; Taplin, Ruth, 1987. Conflict and Conflict Resolution, Lanlam, New York, London. 
Qian, Xin-zhong and Xiao zheng-yu, 1983. "A Survey of the One Thousand Sample survey of Fertility", Beijing; Beijing Economics College, Institution of Population; July.

Renmin Ribao, 1980. "There Should Be No Legislation of Planned Births" Sept. 13.

Smith, Christopher J. 1991. China ---- People and Places in the Land of one Billion. Westview Press.

Tien H. Y. 1981. "Demography in China: From Zero to Now", Population Index, PP683-700.

Walstedt, Joyce 1978. "Reform of Women's Roles and Family Structures in the Recent History of China" Journal of Marriage and the Family. Vol 40, 2, May, PP379-392.

Wang, Xingming, 1991. "Women at the Top of the Ivory Tower", Women of China, Aug., PP4-6

Weeks, John T., 1989. Population -.- An Introduction to Concepts and Issues, 4 th Ed., Wadsworth Publishing Company, Belmont, California, A Division of Wadsorth, Inc.

Weisskopf, Michael, 1985. "China's Crusade Against Children", Washington Post, National Weekly Edition, Jan. PP287-288.

Wolf, Margery, 1985. Revolution Postponed: Women in Contemporary China, Stanford University Press, California.

Women of China, Monthly magazine edited by All-China Women's Federation, Beijing, China. (1985 - 1991)

Wong, siu-lun 1979. Sociology \& Socialism in Contemporary China, Routledge \& Kegan Paul, London.

Worden, Robert L., 1988. China --- a country Study, US Government Printing office.

Xiao, Ming and Chen, Yan, 1989. "Family Planning --- a Hard Nut to Crack", Women of China, Sept.

Yan, Keqing 1983. "Problems \& Prospects in Population Planning", China Reconstructs, June.

Yu, Y.C. 1979. "The Population Policy of China" Population studies. Vol. 33, 1, Mar, 125 - 142 . 
Zhongguo Funu, 1981. "Zhezhong 'xianshi' jiu gaiguan" (We should pole our noses into other people's business), Jan. P44.

Zhongguo Qingnian Bao (China Youth), Aug.29, 1982, I. 
APPENDIX

The following is a list of conditions that enables any couple whether urban or rural to apply for permission to have a second child (Davin, 1985).

1. The first child suffers from a medically-certificated, nonhereditary disability and is not expected to grow up to be an able-bodied laborer.

2. One spouse has a child by a previous marriage but the other does not.

3. A couple believed to be infertile adopt a child after years of marriage and the woman subsequently becomes pregnant.

4. Both spouses are of minority nationality.

5. Both spouses are overseas chinese who have returned from abroad.

Some rural areas have different conditions. The following is the set of conditions issued by Shanxi province in 1982, providing an interesting range of exceptions. ${ }^{18}$

1. The husband has settled in the home of his wife's parents and she is an only child.

18 See "Shanxi Planned Parenthood Regulations", Shanxi Ribao, September,17, 1982 . 
2. They live in sparsely populated mountain villages disadvantaged both in terms of transport and natural conditions.

3. The husband is the only one among three brothers to be capable of fathering a child.

4. The husband is the only son of someone who died for the revolution.

5. One spouse has a major disability.

6. The family has had only one son in a generation for three consecutive generations.

7. Both spouses are themselves only children. 